\title{
Mechanisms Underlying the Antinociceptive, Antiedematogenic, and Anti-Inflammatory Activity of the Main Flavonoid from Kalanchoe pinnata
}

\author{
Raquel Teixeira Ferreira, ${ }^{1}$ Marcela Araújo Soares Coutinho, ${ }^{2}$ \\ David do Carmo Malvar, ${ }^{1}$ Elson Alves Costa, ${ }^{3}$ Iziara Ferreira Florentino, ${ }^{3}$ \\ Sônia Soares Costa, ${ }^{2}$ and Frederico Argollo Vanderlinde ${ }^{1}$ \\ ${ }^{1}$ Laboratory of Pharmacology, Department of Physiological Sciences, Institute of Biology, Federal Rural University of Rio de Janeiro, \\ BR 465, Km 07, 23890-000 Seropédica, RJ, Brazil \\ ${ }^{2}$ Núcleo de Pesquisa de Produtos Naturais, Universidade Federal do Rio de Janeiro, Avenida Carlos Chagas Filho 373, \\ 21941-902 Cidade Universitária, RJ, Brazil \\ ${ }^{3}$ Universidade Federal de Goiás, Instituto de Ciências Biológicas, Departamento de Ciências Fisiológicas, \\ 74001-970 Goiânia, GO, Brazil
}

Correspondence should be addressed to Frederico Argollo Vanderlinde; favanderlinde@gmail.com

Received 30 July 2014; Revised 2 November 2014; Accepted 6 November 2014; Published 11 December 2014

Academic Editor: Jae Youl Cho

Copyright (C) 2014 Raquel Teixeira Ferreira et al. This is an open access article distributed under the Creative Commons Attribution License, which permits unrestricted use, distribution, and reproduction in any medium, provided the original work is properly cited.

Kalanchoe pinnata (KP) is popularly used for treating inflammatory diseases. This study investigated the antinociceptive, antiedematogenic, and anti-inflammatory potential of the subcutaneous administration of KP flower aqueous extract (KPFE), its ethyl acetate (EtOAcF) and butanol (BuOHF) fractions, and the main KP flavonoid [quercetin 3-O- $\alpha$-L-arabinopyranosyl (1 $\rightarrow 2$ ) $\alpha$-L-rhamnopyranoside] (KPFV) in mice, as well as its possible mechanisms of action. KPFE (30-300 mg/kg) and KPFV (1$10 \mathrm{mg} / \mathrm{kg}$ ) inhibited the acetic acid-induced writhing $\left(\mathrm{ID}_{50}=164.8\right.$ and $\left.9.4 \mathrm{mg} / \mathrm{kg}, \mathrm{resp}.\right) . \mathrm{KPFE}(300 \mathrm{mg} / \mathrm{kg}), \mathrm{EtOAcF}(12 \mathrm{mg} / \mathrm{kg})$, $\mathrm{BuOHF}(15 \mathrm{mg} / \mathrm{kg})$, or KPFV $(0.3-3.0 \mathrm{mg} / \mathrm{kg})$ reduced leukocyte migration on carrageenan-induced pleurisy $\left(\mathrm{ID}_{50}=2.0 \mathrm{mg} / \mathrm{kg}\right.$ for KPFV). KPFE (3-30 mg $/ \mathrm{kg})$ and KPFV $(0.3-3.0 \mathrm{mg} / \mathrm{kg})$ reduced the croton oil-induced ear edema $\left(\mathrm{ID}_{50}=4.3 \mathrm{and} 0.76 \mathrm{mg} / \mathrm{kg}\right.$, resp.). KPFE and KPFV reduced the TNF- $\alpha$ concentration in the pleural exudates on carrageenan-induced pleurisy test. Moreover, KPFV inhibited COX-1 $\left(\mathrm{IC}_{50}=22.1 \mu \mathrm{g} / \mathrm{mL}\right)$ and COX-2 $\left(\mathrm{IC}_{50}>50 \mu \mathrm{g} / \mathrm{mL}\right)$. The selectivity index $\left(\mathrm{COX}-1_{\mathrm{IC}_{50}} / \mathrm{COX}-2_{\mathrm{IC}}{ }_{50}\right)$ was $<0.44$. These results indicate that KPFE and KPFV produced antinociceptive, antiedematogenic, and anti-inflammatory activities through COX inhibition and TNF- $\alpha$ reduction, revealing that the main flavonoid in KP flowers and leaves plays an important role in the ethnomedicinal use of the plant.

\section{Introduction}

Kalanchoe pinnata (Lamarck) Persoon (= Bryophyllum pinnatum), one of the most important medicinal species of the family Crassulaceae, is used in folk medicine to treatment of many diseases such as cardiovascular dysfunctions [1] and diabetes [2] and for healing wounds and treating inflammations $[3,4]$. The leaves from this plant are the part most commonly used and therefore have been the focus of a variety of chemical and pharmacological studies. Several studies have reported antiviral, antimicrobial, antiulcer, antileishmanial, hepatoprotective, antioxidant, and antihyperglycemic activities from leaves of $K$. pinnata [1,2,5]; to review see [4]. Recent studies have shown the potential activity of KP leaves in inhibiting inflammatory events related to allergic airway diseases [6]. Anti-inflammatory activity has also been reported for KP leaves [7-9]. Polyphenolic compounds present in the extract are speculated to be responsible for this activity. Although many studies have been carried out with KP leaves, there are few works devoted to the flowers of this species [3].

Recently we demonstrated the immunosuppressive potential of the aqueous extract from KP flowers. The KPFE 
proved to be more active than the aqueous leaf extract in inhibiting murine T-cell mitogenesis in vitro. In addition, five quercetin-derivative flavonoids isolated from the flower extract showed potent inhibitory activity against murine T-cell mitogenesis as well as on IL- 2 and IL- 4 production, without cell toxicity [10]. Flavonoids are the main phenolic compounds in the Kalanchoe species [3] and are of great pharmacological importance [11]. Some studies have demonstrated a direct relation between the anti-inflammatory effects of various flavonoids and cyclooxygenases 1 and 2 [12], leading to a reduction of important anti-inflammatory mediators such as prostaglandin $\mathrm{E}_{2}$ [13]. Additionally, other studies have revealed the efficacy of flavonoids in the reduction of TNF- $\alpha$ levels [14-16] through the ability to reduce the expression of some genes linked with proinflammatory events [14] and the circulating levels of TNF- $\alpha$ in humans [16].

Considering the promising preliminary results with KP flowers and the relevant therapeutic potential of this species, the aim of this study was to investigate the antinociceptive, antiedematogenic, and anti-inflammatory activities of the KP flowers aqueous extract, the two enriched-flavonoid fractions, and the main KPF flavonoid [quercetin 3-O- $\alpha$-Larabinopyranosyl $(1 \rightarrow 2) \alpha$-L-rhamnopyranoside] (here denominated as KPFV) on pharmacological inflammation models.

\section{Material and Methods}

2.1. Plant Material. Flowers of Kalanchoe pinnata (Lamarck) Persoon were collected from specimens cultivated in the UFRJ campus, Brazil, in September 2011, and identified by the botanist M. F. Freitas at the herbarium of the Rio de Janeiro Botanical Garden. A voucher specimen (292.697) is deposited at the Herbarium of the Rio de Janeiro Botanical Garden (Brazil).

2.2. Extraction and Isolation. Fresh flowers $(2.52 \mathrm{~kg})$ were ground and extracted with distilled water at $20 \% \mathrm{w} / \mathrm{v}$ for $30 \mathrm{~min}$ at $50^{\circ} \mathrm{C}$. The yield of lyophilized flower extract (KPFE) was $3.82 \%$ (90.2 g) from the initial fresh material. Dried flower extract was resuspended in distilled water $(2.1 \mathrm{~L})$ and precipitated with EtOH $(1: 1)$. The soluble fraction $(76.9 \mathrm{~g})$ was partitioned with ethyl acetate $(1 \times 550 \mathrm{~mL} ; 2 \times 225 \mathrm{~mL})$, affording EtOAcF (5.58 g; 6.2\%, wt/wt of dried KPFE extract). The residual soluble fraction $(71.38 \mathrm{~g})$ was then partitioned with $n$-butanol $(1 \times 550 \mathrm{~mL} ; 2 \times 225 \mathrm{~mL})$, affording $\mathrm{BuOHF}$ (12.35 g; 13.7\%, wt/wt of dried KPFE extract). The flavonoid quercetin $3-O-\alpha$-L-arabinopyranosyl $(1 \rightarrow 2) \alpha$-Lrhamnopyranoside (KPFV) was isolated (95\% purity; retention time 31.2 minutes) according to procedures previously reported [10].

HPLC chromatograms of Kalanchoe pinnata flowers extract, organic fractions, and isolated flavonoid [quercetin 3$O$ - $\alpha$-L-arabinopyranosyl $(1 \rightarrow 2) \alpha$-L-rhamnopyranoside] (KPFV), along with ${ }^{1} \mathrm{H}$ and ${ }^{13} \mathrm{C}-\mathrm{NMR}$ spectra of the flavonoid, are available online in Supplementary Material (at http://dx.doi.org/10.1155/2014/429256).
2.3. Drugs. The drugs used were dexamethasone (Decadron, Aché Lab. Farm, São Paulo, Brazil), carrageenan, indomethacin, croton oil (Sigma Chemical Co., St. Louis, USA), and acetone (Merck AG, Darmstadt, Germany), acetic acid, and PBS solution. The lyophilized KP flower extract (KPFE), the butanol (BuOHF) and ethyl acetate (EtOAcF) KP fractions, the flavonoid [quercetin 3-O- $\alpha$-L-arabinopyranosyl $(1 \rightarrow 2)$ $\alpha$-L-rhamnopyranoside] (KPFV), and the drugs were diluted in saline $0.9 \%$ in such a concentration so as to allow the administration of $10 \mathrm{~mL} / \mathrm{kg}$, by subcutaneous (s.c.) route, for each dose employed. EtOAcF, BuOHF, and KPFV doses were determined according to their yields from KPFE.

2.4. Animals. The experimental protocols in the pharmacological assays using adult male Swiss mice (25-35 g) were approved by the local Animal Care and Use Committee (3403/2011/COMEP/UFRRJ).

2.5. Acetic Acid-Induced Abdominal Writhing. Groups of mice ( $n=5-6)$ were treated subcutaneously with saline, $\operatorname{KPFE}(30,100$, and $300 \mathrm{mg} / \mathrm{kg}), \operatorname{KPFV}(1,3$, and $10 \mathrm{mg} / \mathrm{kg})$, or the positive control indomethacin $(10 \mathrm{mg} / \mathrm{kg}) 30 \mathrm{~min}$ before acetic acid injection $(1.2 \%, 0.1 \mathrm{~mL} / 10 \mathrm{~g})$ and the number of writhings was counted for the following $30 \mathrm{~min}$ [17]. The results were expressed as means \pm SEM of number of writhings allowing the $\mathrm{ID}_{50}$ value calculation.

2.6. Carrageenan-Induced Pleurisy. Groups of mice $(n=8)$ were treated subcutaneously with saline, KPFE $(300 \mathrm{mg} / \mathrm{kg})$, $\mathrm{KP}$ fractions $(\mathrm{BuOHF}=15 \mathrm{mg} / \mathrm{kg} ; \mathrm{EtOAcF}=12 \mathrm{mg} / \mathrm{kg})$, $\operatorname{KPFV}(0.3,1.0$, and $3.0 \mathrm{mg} / \mathrm{kg})$, or dexamethasone $(2 \mathrm{mg} / \mathrm{kg})$ $30 \mathrm{~min}$ prior to an injection of carrageenan (1\% in saline) into the pleural cavity. After four hours the pleural exudate was collected with $1 \mathrm{~mL}$ of heparinized PBS and the total number of leukocytes was counted in a Neubauer chamber [18].

2.7. Croton Oil-Induced Mice Ear Edema. Groups of mice ( $n=8-11)$ were treated subcutaneously with saline, KPFE $(3,10$, and $30 \mathrm{mg} / \mathrm{kg}), \mathrm{KPFV}(0.3,1.0$, and $3.0 \mathrm{mg} / \mathrm{kg})$, or dexamethasone $(2 \mathrm{mg} / \mathrm{kg}) 30 \mathrm{~min}$ before application of croton oil (2.5\% in acetone, $20 \mu \mathrm{L}$ ) on the inner surface of the right ear. The weight difference $(\Delta)$ between the right ears (croton oil, $2.5 \%$ ) and left ears (acetone) was measured four hours after croton oil application [18].

\subsection{Evaluation of Action Mechanisms}

2.8.1. TNF- $\alpha$ Ex Vivo Measurement. Groups of mice $(n=8)$ were treated subcutaneously with saline, KPFE $(300 \mathrm{mg} / \mathrm{kg})$, $\mathrm{KPFV}$ (3 mg/kg), or dexamethasone $(2 \mathrm{mg} / \mathrm{kg}) 30 \mathrm{~min}$ prior to carrageenan injection ( $1 \%$ in saline; $500 \mu \mathrm{L} /$ mouse) into the pleural cavity. Four hours after carrageenan administration, the pleural exudate was collected with $1 \mathrm{~mL}$ of heparinized PBS. An aliquot was used to evaluate TNF- $\alpha$ concentrations in pleural exudate through an immunosorbent assay kit (ELISA) (Ebioscience, San Diego, CA, USA). Results were expressed as means \pm SEM of TNF- $\alpha$ concentration (pg/mL) [19]. 


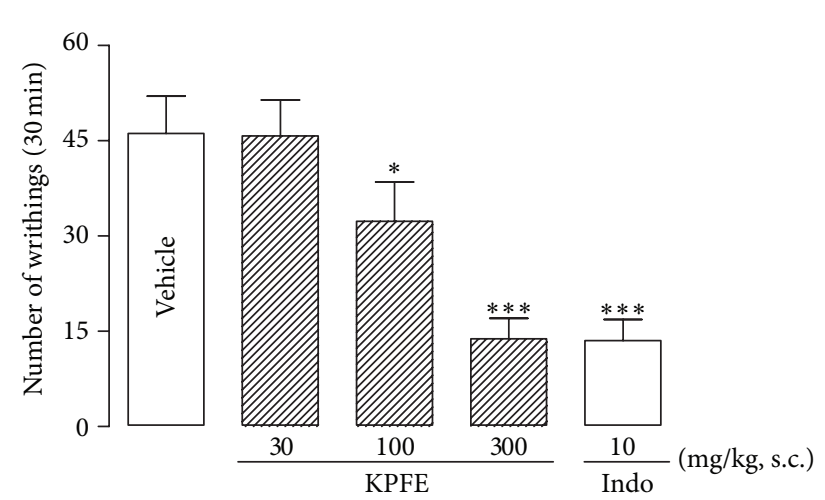

(a)

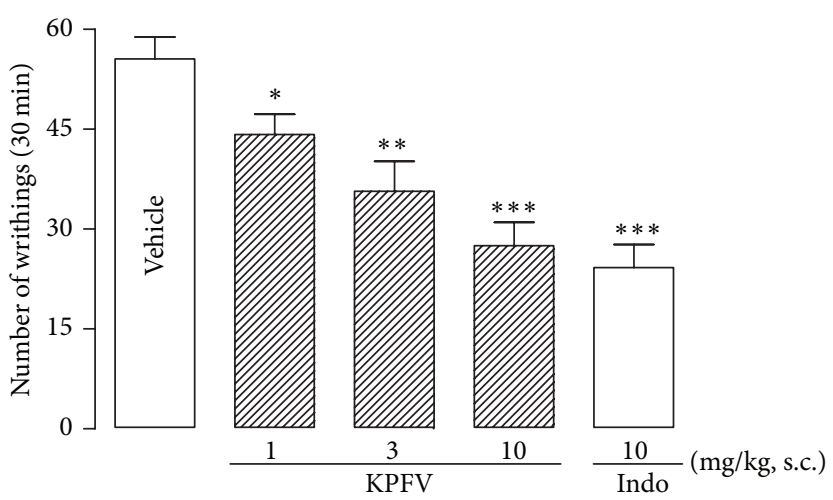

(b)

FIGURE 1: Effect of KPFE (a) and KPFV (b) on the acetic acid-induced abdominal writhing test. KPFE, KPFV, or indomethacin (Indo) was subcutaneously administrated $30 \mathrm{~min}$ before acetic acid injection $(1.2 \%, 0.1 \mathrm{~mL} / 10 \mathrm{~g})$. The number of acetic acid-induced abdominal writhings was counted for the following $30 \mathrm{~min} .{ }^{*} P<0.05,{ }^{* *} P<0.01$, and ${ }^{* * *} P<0.001$ significantly different from the vehicle-treated group. Values represent the mean \pm SEM of 5-6 mice.

2.8.2. In Vitro Cyclooxygenase (COX) Inhibition Assay. The inhibitory effect of KPFV and the positive control indomethacin on COX-1/COX-2 enzymatic activity were determined using a colorimetric COX (ovine) inhibitor screening assay kit (Cayman Chemical, Catalogue number 760111) according to the protocol recommended by the supplier [19]. The range of KPFV concentrations used for evaluation of both COX activities was from 3.125 to $50 \mu \mathrm{g} / \mathrm{mL}$, while the ranges of indomethacin concentration were from 2.5 to $80 \mu \mathrm{g} / \mathrm{mL}$ and from 18.75 to $600 \mu \mathrm{g} / \mathrm{mL}$ for COX-1 and COX-2 activity, respectively.

2.9. Statistical Analysis. Data were statistically analyzed with GraphPad Prism 5, and the results were expressed as mean \pm SEM. Differences among the groups were calculated using one-way ANOVA followed by Tukey-Kramer test, and test data were considered different at a significance level of $P<$ 0.05 .

\section{Results}

Purification of aqueous extract from KP flowers (KPFE) afforded two enriched-flavonoid fractions: EtOAcF (6.2\%) and $\mathrm{BuOHF}(13.7 \%)$.

Pretreatment (s.c.) of mice with KPFE at 100 and $300 \mathrm{mg} / \mathrm{kg}$ produced antinociception evidenced by the reduction of the number of acetic acid-induced writhings (w) by $30.1 \%(32.3 \pm 6.2 \mathrm{w})$ and $70.1 \%(13.8 \pm 3.2 \mathrm{w})$, respectively $\left(\mathrm{ID}_{50} 164.8 \mathrm{mg} / \mathrm{kg}\right)$, comparatively with vehicle group (46.2 \pm $5.8 \mathrm{w})$, while the positive control indomethacin $(10 \mathrm{mg} / \mathrm{kg})$ reduced by $70.8 \%(13.5 \pm 3.4 \mathrm{w})$ and $\mathrm{KPFE}(30 \mathrm{mg} / \mathrm{kg})$ was ineffective (Figure 1(a)).

The main flavonoid $\operatorname{KPFV~}(1,3$, and $10 \mathrm{mg} / \mathrm{kg})$ also produced a dose-related inhibition of the number of acetic acid-induced writhing by $20.5 \%(44.2 \pm 3.1 \mathrm{w}), 35.8 \%$ $(35.7 \pm 4.5 \mathrm{w})$, and $50.5 \%(27.5 \pm 3.5 \mathrm{w})$, respectively $\left(\mathrm{ID}_{50}\right.$ $9.4 \mathrm{mg} / \mathrm{kg})$, when compared with vehicle group $(55.6 \pm 3.3 \mathrm{w})$. As expected, the positive control indomethacin $(10 \mathrm{mg} / \mathrm{kg})$ reduced the number of writhings by $56.5 \%(24.2 \pm 3.5 \mathrm{w})$ (Figure 1(b)).

In the carrageenan-induced pleurisy assay the pretreatment (s.c.) with KPFE (300 mg/kg), EtOAcF (12 mg/kg), $\mathrm{BuOHF}(15 \mathrm{mg} / \mathrm{kg}$ ), or dexamethasone (positive control group $-2 \mathrm{mg} / \mathrm{kg}$ ) reduced the leukocyte migration into the pleural cavity by $56.1 \%\left(2.5 \pm 0.2\right.$ leukocytes $\left.\times 10^{6} / \mathrm{mL}\right)$, $47.3 \%\left(3.0 \pm 0.3\right.$ leukocytes $\left.\times 10^{6} / \mathrm{mL}\right), 39.6 \%(3.4 \pm 0.3$ leukocytes $\left.\times 10^{6} / \mathrm{mL}\right)$, and $43.9 \%(3.2 \pm 0.6$ leukocytes $\times$ $10^{6} / \mathrm{mL}$ ), respectively, when compared to the vehicle-treated group $\left(5.7 \pm 0.7\right.$ leukocytes $\times 10^{6} / \mathrm{mL}$ ) (Figure $2(\mathrm{a})$ ).

$\mathrm{KPFV}(0.3,1.0$, and $3.0 \mathrm{mg} / \mathrm{kg})$ also exhibited a doserelated reduction of leukocyte migration by $8.0 \%(6.9 \pm 0.6$ leukocytes $\left.\times 10^{6} / \mathrm{mL}\right), 38.8 \%\left(4.6 \pm 0.2\right.$ leukocytes $\left.\times 10^{6} / \mathrm{mL}\right)$, and $57.2 \%\left(3.2 \pm 0.3\right.$ leukocytes $\left.\times 10^{6} / \mathrm{mL}\right)$, respectively $\left(\mathrm{ID}_{50} 2.0 \mathrm{mg} / \mathrm{kg}\right)$, whereas the treated with dexamethasone $(2 \mathrm{mg} / \mathrm{kg})$, positive control group, inhibited by $71.9 \%(2.1 \pm$ 0.2 leukocytes $\times 10^{6} / \mathrm{mL}$ ) when compared with the vehicletreated group $\left(7.5 \pm 0.6\right.$ leukocytes $\times 10^{6} / \mathrm{mL}$ ) (Figure 2(b)).

$\operatorname{KPFE}(3,10$, or $30 \mathrm{mg} / \mathrm{kg}$, s.c.) produced a dose-related antiedematogenic effect evidenced by the reduction in croton oil-induced mice ear edema by $50.8 \%(\Delta=2.9 \pm 0.5 \mathrm{mg})$, $54.2 \%(\Delta=2.7 \pm 0.7 \mathrm{mg})$, and $64.4 \%(\Delta=2.1 \pm 0.5 \mathrm{mg})$, respectively, whereas dexamethasone $(2 \mathrm{mg} / \mathrm{kg})$ reduced the edema by $81.4 \%(\Delta=1.1 \pm 0.3 \mathrm{mg})$ when compared with the vehicle treated group $(\Delta=5.9 \pm 1.0 \mathrm{mg})$, with $\mathrm{ID}_{50} 4.3 \mathrm{mg} / \mathrm{kg}$ (Figure 3(a)).

In another experimental set, pretreatment with the main flavonoid $\operatorname{KPFV}(0.3,1.0$, or $3.0 \mathrm{mg} / \mathrm{kg}$, s.c.) also produced a dose-related antiedematogenic effect in the croton oilinduced mice ear edema by $38.2 \%(\Delta=4.2 \pm 0.4 \mathrm{mg}), 54.4 \%$ $(\Delta=3.1 \pm 0.4 \mathrm{mg})$, and $70.6 \%(\Delta=2.0 \pm 0.4 \mathrm{mg})$, respectively, whereas the treatment with dexamethasone $(2 \mathrm{mg} / \mathrm{kg})$ reduced the ear edema by $85.3 \%(\Delta=1.0 \pm 0.4 \mathrm{mg})$ when compared with the vehicle group $(\Delta=6.8 \pm 0.6 \mathrm{mg})$, with $\mathrm{ID}_{50}$ $0.76 \mathrm{mg} / \mathrm{kg}$ (Figure 3(b)).

After intrapleural injection of carrageenan, the pretreatment with $\mathrm{KPFE}(300 \mathrm{mg} / \mathrm{kg}$, s.c.) or dexamethasone 


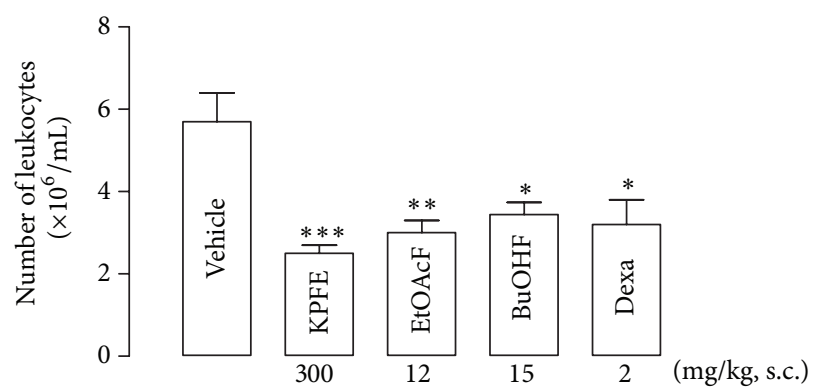

(a)

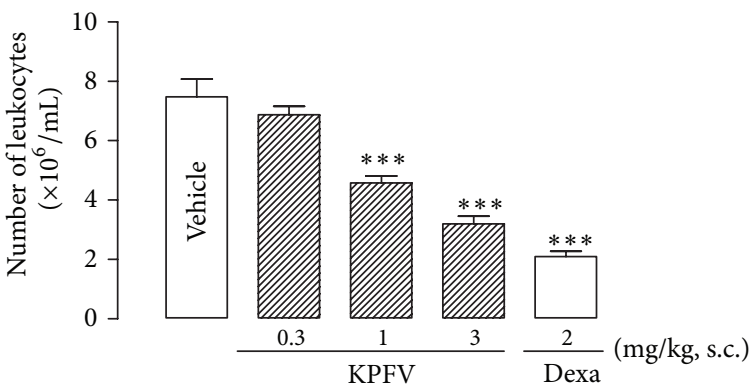

(b)

Figure 2: Effect of KPFE, KP fractions (a) and KPFV (b) in the carrageenan-induced pleurisy. KPFE, KP fractions (EtOAcF and BuOHF), KPFV, or dexamethasone (Dexa) was subcutaneously administrated $30 \mathrm{~min}$ before carrageenan injection $(1 \%, 0.1 \mathrm{~mL} / 10 \mathrm{~g})$. After four hours, the pleural exudate was collected and the total number of leukocytes was counted in a Neubauer chamber. ${ }^{*} P<0.05$, ${ }^{* *} P<0.01$, and ${ }^{* * *} P<0.001$ significantly different from the vehicle-treated group. Values represent the mean \pm SEM of 8 mice.

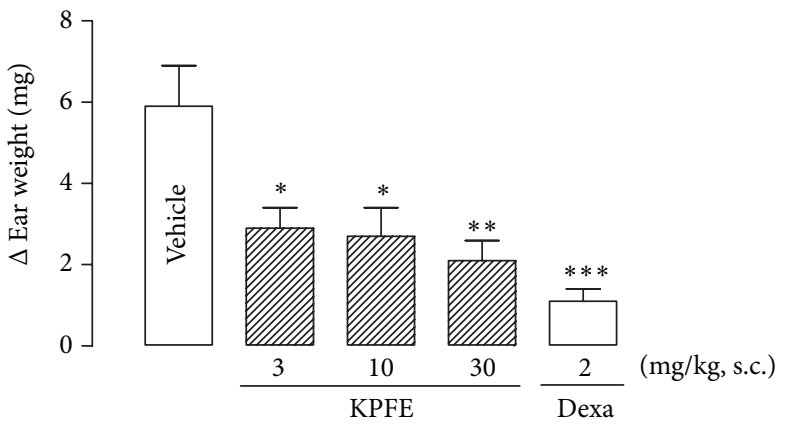

(a)

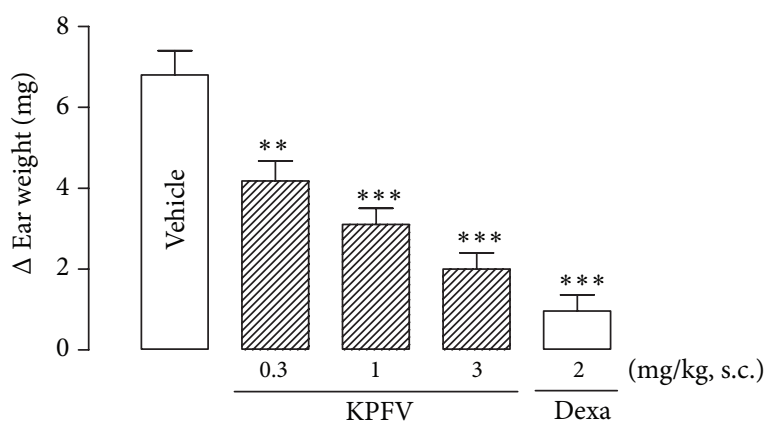

(b)

FIGURE 3: Effect of KPFE (a) and KPFV (b) on the croton oil-induced mice ear edema. KPFE, KPFV, or dexamethasone (Dexa) was subcutaneously administrated $30 \mathrm{~min}$ before application of croton oil $(2.5 \%$ in acetone, $20 \mu \mathrm{L})$ or acetone on the inner surface of the right and left ear, respectively. After four hours, the weight difference $(\Delta)$ between the right and left ears was measured. ${ }^{*} P<0.05$, ${ }^{* *} P<0.01$, and ${ }^{* * *} P<0.001$ significantly different from the vehicle-treated group. Values represent the mean \pm SEM of 10 mice.

$(2 \mathrm{mg} / \mathrm{kg}$, s.c.) reduced the TNF- $\alpha$ concentration in pleural exudates $(P<0.001)$ by $44.7 \%(47.6 \pm 0.3 \mathrm{pg} / \mathrm{mL})$ and $69.8 \%(26.0 \pm 2.0 \mathrm{pg} / \mathrm{mL})$, respectively, when compared to the vehicle group $(86.0 \pm 2.0 \mathrm{pg} / \mathrm{mL})$ (Figure $4(\mathrm{a})$ ).

In an additional experiment, the flavonoid KPFV $(3.0 \mathrm{mg} / \mathrm{kg}$, s.c.) decreased the TNF- $\alpha$ concentration in pleural exudates by $66.6 \%(22.6 \pm 3.1 \mathrm{pg} / \mathrm{mL})$ when compared to the vehicle group $(67.5 \pm 4.9 \mathrm{pg} / \mathrm{mL})$. As expected, dexamethasone $(2 \mathrm{mg} / \mathrm{kg}$, s.c.) also reduced the TNF- $\alpha$ concentration by $74.5 \%(17.2 \pm 3.2 \mathrm{pg} / \mathrm{mL})$ (Figure 4(b)).

The flavonoid KPFV inhibited both COX-1 and COX-2 in vitro activities (Table 1 ), and the $\mathrm{IC}_{50}$ calculated for COX1 inhibition was $3.8 \times 10^{-5} \mathrm{M}(22.1 \mu \mathrm{g} / \mathrm{mL})$. The maximum COX-2 inhibition induced by KPFV was $43.5 \%(50 \mu \mathrm{g} / \mathrm{mL})$; therefore the $\mathrm{IC}_{50}$ for COX-2 inhibition was $>8.4 \times 10^{-5} \mathrm{M}$. The selectivity index (SI; COX- $1_{\mathrm{IC}_{50}} / \mathrm{COX}-2_{\mathrm{IC}_{50}}$ ) was $<0.44$. The positive control indomethacin also inhibited both COX1 and COX-2 activities ( $\mathrm{IC}_{50}$ for COX-1 and COX-2 was 5.9 and $31.2 \mu \mathrm{g} / \mathrm{mL}$, resp., and SI was 0.19).

\section{Discussion}

The anti-inflammatory potential of $K$. pinnata leaves was evaluated previously in different models [7-9]. Hema et al. [7] attributed the anti-inflammatory activity to the presence of
TABLE 1: Effect of flavonoid KPFV on COX-1 and COX-2 activities.

\begin{tabular}{lcc}
\hline $\begin{array}{l}\text { KPFV concentration } \\
(\mu \mathrm{g} / \mathrm{mL})\end{array}$ & \multicolumn{2}{c}{ Inhibition (\%) } \\
\hline 3.125 & COX-1 & COX-2 \\
6.25 & 44.2 & 18.5 \\
12.5 & 46.1 & 20.4 \\
25.0 & 49.0 & 26.9 \\
50.0 & 50.0 & 38.9 \\
\hline
\end{tabular}

sitosterol and aliphatic alcohols without testing any isolated compound. In the same way, there are also some reports that attribute this action to flavonoids $[8,9]$.

Our research group has been studying, via an interdisciplinary approach, the chemical composition of KP leaves taking into consideration their traditional use for healing wounds and other inflammatory processes. Our findings have demonstrated that KP flavonoids, isolated from the KP leaves extract, possess significant activity in leishmaniasis, asthma, and antiallergenic models, through immunomodulating mechanisms $[3,6]$. 


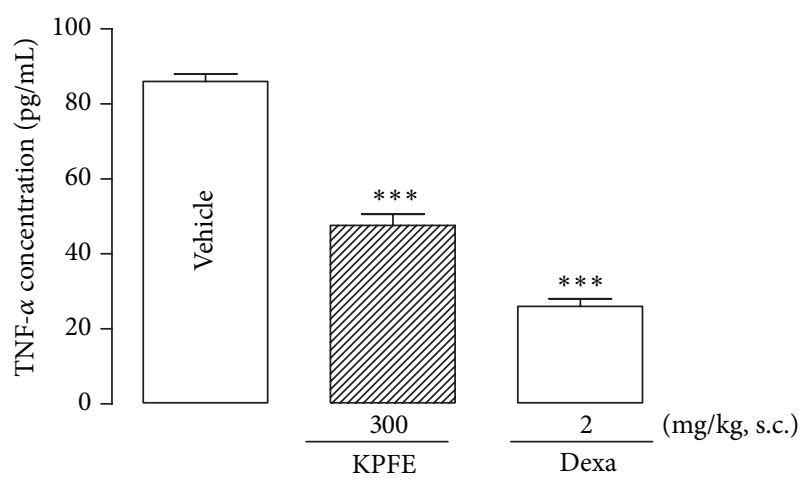

(a)

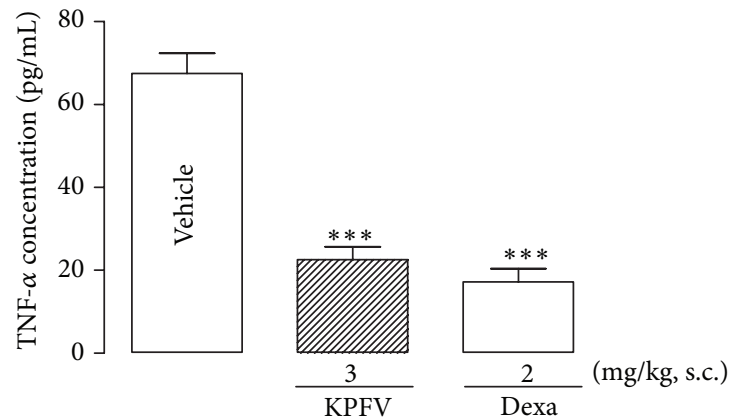

(b)

FIGURE 4: Effect of KPFE (a) and KPFV (b) on TNF- $\alpha$ concentration in the pleural exudates. KPFE, KPFV, or dexamethasone (Dexa) was subcutaneously administrated $30 \mathrm{~min}$ before carrageenan injection $(1 \%, 0.1 \mathrm{~mL} / 10 \mathrm{~g})$. The pleural exudates were collected $4 \mathrm{~h}$ after the carrageenan injection. TNF- $\alpha$ concentration was determined by ELISA. ${ }^{* * *} P<0.001$ significantly different from the vehicle-treated group. Values represent means \pm SEM of the TNF- $\alpha$ concentration in the pleural exudates $(\mathrm{pg} / \mathrm{mL})$ of 8 mice per group.<smiles>O=c1c(OC2OC(C(O)O)C3OCC(O)C(O)C3OC2C(O)O)c(-c2ccc(O)c(O)c2)oc2cc(O)cc(O)c12</smiles>

FIGURE 5: Structure of the main flavonoid from KP flowers: quercetin 3-O- $\alpha$-L-arabinopyranosyl $(1 \rightarrow 2) \alpha$-L-rhamnopyranoside (KPFV).

Although the flowers present a higher content and variety of flavonoids, there are few studies of the isolation and characterization of bioactive molecules from the KP flowers or their pharmacological potential. Our previous study on the chemical composition of KP flowers led to the isolation of four flavonol glycosides, as well as a flavonol aglycone. Quercetin 3-O- $\alpha$-L-arabinopyranosyl $(1 \rightarrow 2) \alpha$-Lrhamnopyranoside (KPFV) (Figure 5) proved to be the most abundant flavonoid in KP flowers $(1.87 \% \mathrm{wt} / \mathrm{wt})$ [10] and therefore is the aim of the present study. The other flavonoids isolated by our group were quercetin 3-O- $\beta$-glucuronopyranoside (miquelianin, $0.79 \% \mathrm{wt} / \mathrm{wt}$ ), quercetin $3-O-\beta$ glucopyranoside (isoquercitrin, $0.21 \% \mathrm{wt} / \mathrm{wt}$ ), quercetin 3 $O$ - $\alpha$-L-rhamnopyranoside (quercitrin, $0.25 \% \mathrm{wt} / \mathrm{wt}$ ), and quercetin $(0.12 \% \mathrm{wt} / \mathrm{wt})$. These flavonoids were considered to be the minority compounds [10].
The aglycone quercetin present in the chemical structure of KPFV proved to be an anti-inflammatory and immunosuppression agent $[20,21]$. This flavonol has a well-known immunomodulatory effect through the regulation of inflammatory mediators, such as inhibiting cytokine and inducible nitric oxide synthase expression via inhibition of the NF- $\kappa \beta$ pathway [15, 22]. Moreover, quercetin has been reported as having anti-inflammatory properties in experimental murine allergic asthma [23]. A study using human peripheral blood mononuclear cells showed the quercetin role in modulating the TNF- $\alpha$ production and gene expression, and this effect is linked to the modulation of the NF- $\kappa \beta 1$ and I $\kappa \beta$ pathways [24]. This flavonoid also inhibits $\mathrm{PGE}_{2}$ and nitric oxide production in IFN- $\gamma$ and lipopolysaccharide-stimulated RAW 264.7 cells [25].

The content of the diglycosyl flavonoid KPFV in KP flowers is more than 2 times greater than the content of miquelianin. When comparing with isoquercitrin and quercitrin, the content of KPFV is 9 and 7 times higher, respectively. Recently we have shown that KPFV impairs T-cell proliferation $\left(\mathrm{IC}_{50} 38.8 \mu \mathrm{g} / \mathrm{mL}\right.$ ) and it was able to inhibit the production of IL-2 and IL- 4 cytokines [10]. The use of this flavonoid for antiallergenic purpose was the basis of a Japanese patent [26].

In present study the aqueous extract from $K$. pinnata flowers (KPFE) produced a dose-related inhibition of acetic acid-induced writhing indicating the antinociceptive activity. The main flavonoid (KPFV) also produced antinociceptive activity in the acetic acid-induced writhing model using doses up to 30 times lower than KPFE, suggesting the involvement of flavonoids, especially KPFV, in the antinociceptive effect of the flower extracts. The nociception induced by this assay is mediated by cyclooxygenase, such as $\mathrm{PGE}_{2}$, $\mathrm{PGF}_{2 \alpha}$, and $\mathrm{PGI}_{2}$, and lipoxygenase products, such as $\mathrm{LTB}_{4}$ $[27,28]$, which can explain its sensitivity by nonsteroidal antiinflammatory drugs (NSAIDs) such as indomethacin [29].

Later, the anti-inflammatory effect of KPFE and the enriched-flavonoid fractions (EtOAcF and BuOHF) was evidenced by the reduction in the total leukocyte migration 
to the pleural cavity induced by carrageenan. This result could be explained, at least partially, by the high content of KPFV flavonoid in the EtOAcF (22.9\%) and $\mathrm{BuOHF}$ (39.5\%) fractions. Moreover, KPFV exhibited the same effect at doses up to 100 times lower than KPFE, demonstrating that KPFV is also involved in the anti-inflammatory effect of the flower extracts. Furthermore, carrageenan-induced leukocyte migration is dependent on the synthesis/release of the chemoattractants mediators leukotrienes such as LTB4 [30], cytokines IL-1 and TNF- $\alpha$ [31], and chemokines [32]. Pretreatment with KPFE or its main flavonoid KPFV reduced the TNF- $\alpha$ concentration in pleural exudates, suggesting that they produce an anti-inflammatory effect, at least in part, by TNF- $\alpha$ inhibition.

The anti-inflammatory activities of KPFE and its main flavonoid were also evidenced by the croton oil-induced ear edema test. Topical application of croton oil induces an acute inflammatory response mainly characterized by fluid accumulation and edema formation. The edema formation is initially mediated by histamine and serotonin and later by the release of prostaglandins [28]. 12-O-Tetradecanoylphorbol13-acetate, a phorbol ester present in croton oil, has been reported to stimulate phospholipid-dependent protein kinase $\mathrm{C}$ and the overexpression of inducible nitric oxide synthase and cyclooxygenase-2 [33]. In this inflammatory model the dose-related inhibition of KPFE was detected at doses up to 100 times smaller ( 3 to $30 \mathrm{mg} / \mathrm{kg}$ ) than used in leukocyte migration. Similarly, KPFV produced a reduction of edema formation and its effectiveness was obtained using lower doses when compared to KPFE and was active from $0.3 \mathrm{mg} / \mathrm{kg}$. These findings are very promising considering that, recently, the anti-inflammatory activity of the leaf extract from KP was attributed to a novel steroid derivative, when Afzal et al. [34], using the model of carrageenaninduced rat paw edema and oral administration, showed that the extract $(400 \mathrm{mg} / \mathrm{kg})$ and the steroid $(300 \mathrm{mg} / \mathrm{kg})$ reduced the inflammation by $87 \%$ and $84 \%$, respectively. These authors [34] needed to administer a high dose of the steroid compound from the leaf extract to obtain approximately the same effect as our results using the KPFV flavonoid. Furthermore, KPFE and KPFV produce antiedematogenic effect at lower doses than those required to produce antinociceptive effects, suggesting that they are more effective to produce the antiedematogenic and anti-inflammatory effects than the antinociceptive effect, as observed to other extracts or isolated compounds [35-37].

Prostaglandins play an important role in the setting of the cardinal signs of inflammation, pain, heat, redness, edema, and loss of function. The biosynthesis of $\mathrm{PGE}_{2}$, the main inflammatory prostaglandin, involves three key enzymes, phospholipase $\mathrm{A}_{2}\left(\mathrm{PLA}_{2}\right)$, cyclooxygenase (COX), and PGE synthase (PGES) [38]. Some flavonoids may reduce $\mathrm{PGE}_{2}$ synthesis by inhibiting the activity of these enzymes or by inhibiting the expression of the inflammatory-induced enzymes, COX-2, or microsomal PGES-1 [13, 39, 40]. Our results demonstrated that $\mathrm{KPFV}$, as well as the positive control indomethacin, inhibited the activity of both COX-1 and COX-2. Its selectivity index (SI; COX-1 ${ }_{\mathrm{IC}_{50}} / \mathrm{COX}-2_{\mathrm{IC}_{50}}$ ) was $<0.44$, indicating that KPFV has a slightly preferential inhibition to COX-1. These results indicate that KPFE and its main flavonoid also produce an anti-inflammatory effect by prostaglandins synthesis inhibition through COX inhibition. However, the involvement of other mechanisms of prostaglandins synthesis inhibition remains to be evaluated.

It is worth mentioning that quercetin 3-O- $\alpha$-L-arabinopyranosyl $(1 \rightarrow 2) \alpha$-L-rhamnopyranoside (KPFV) is the most abundant flavonoid in both flowers $(1.87 \% \mathrm{w} / \mathrm{w})$ and leaves $(2.26 \% \mathrm{w} / \mathrm{w})$, as reported before [10]. Although this study has focused on the flowers of KP, it seems plausible that these results obtained with KPFV can be extended to the leaves. Thus, the presence of this flavonoid in the leaves must explain at least partially the popular use of the plant in inflammatory disorders.

\section{Conclusions}

For the first time the antinociceptive, antiedematogenic, and anti-inflammatory effects of $K$. pinnata flowers and its main flavonoid were described. These effects involve COX-1/COX-2 and TNF- $\alpha$ synthesis/release inhibition. The demonstration of the antinociceptive, antiedematogenic, and anti-inflammatory activities of the main flavonoid present in flowers and leaves $[3,10]$ of this species represents a major breakthrough in the pharmacological knowledge of a medicinal plant widely used in inflammatory processes.

\section{Conflict of Interests}

The authors declare that there is no conflict of interests regarding the publication of this paper.

\section{Authors' Contribution}

Raquel Teixeira Ferreira and Marcela Araújo Soares Coutinho contributed equally to this study.

\section{Acknowledgments}

The authors are grateful to CAPES (Brazil) for fellowships to Marcela Araújo Soares Coutinho and Raquel Teixeira Ferreira, Fundação Carlos Chagas Filho de Amparo à Pesquisa do Estado do Rio de Janeiro, Brazil (FAPERJ), and Programa Multicêntrico de Pós-graduação em Ciências Fisiológicas da Sociedade Brasileira de Fisiologia for financial support.

\section{References}

[1] O. S. M. Bopda, F. Longo, T. N. Bella et al., "Antihypertensive activities of the aqueous extract of Kalanchoe pinnata (Crassulaceae) in high salt-loaded rats," Journal of Ethnopharmacology, vol. 153, no. 2, pp. 400-407, 2014.

[2] E. F. Aransiola, M. O. Daramola, E. O. Iwalewa, A. M. Seluwa, and O. O. Olufowobi, "Anti-diabetic effect of Bryophyllum pinnatum leaves," International Journal of Biological, Life Science and Engineering, vol. 8, no. 1, pp. 51-55, 2014. 
[3] S. S. Costa, M. F. Muzitano, L. M. M. Camargo, and M. A. S. Coutinho, "Therapeutic potential of Kalanchoe species: flavonoids and other secondary metabolites," Natural Product Communications, vol. 3, no. 12, pp. 2151-2164, 2008.

[4] R. Milad, S. El-Ahmady, and A. N. Singab, "Genus Kalanchoe (Crassulaceae): a review of its ethnomedicinal, botanical, chemical and pharmacological properties," European Journal of Medicinal Plants, vol. 4, no. 1, pp. 86-104, 2014.

[5] C. Aoki, S. Hartati, M. R. Santi et al., "Isolation and identification of substances with anti-hepatitis c virus activities from Kalanchoe pinnata," International Journal of Pharmacy and Pharmaceutical Sciences, vol. 6, no. 2, pp. 211-215, 2014.

[6] E. A. Cruz, S. Reuter, H. Martin et al., "Kalanchoe pinnata inhibits mast cell activation and prevents allergic airway disease," Phytomedicine, vol. 19, no. 2, pp. 115-121, 2012.

[7] D. Hema, M. Tidjani, E. Bsssene, L. Posset, and H. GionoBarber, "Plantes médicinales africaines XXIV étude de laction anti-inflammatoire de Bryophyllum pinnatum (Crassulaceae)," Plantes Médicinales et Phytothérapie, vol. 20, no. 3, pp. 231-235, 1986.

[8] J. A. O. Ojewole, "Antinociceptive, anti-inflammatory and antidiabetic effects of Bryophyllum pinnatum (Crassulaceae) leaf aqueous extract," Journal of Ethnopharmacology, vol. 99, no. 1, pp. 13-19, 2005.

[9] P. J. C. Sousa, J. C. S. Rocha, A. M. Pessoa, L. A. D. Alves, and J. C. T. Carvalho, "Preliminar study of the anti-inflammatory activity of Bryophillum calycinum Salisb," Revista Brasileira de Farmacognosia, vol. 15, no. 1, pp. 60-64, 2005.

[10] M. A. S. Coutinho, M. F. Muzitano, E. A. Cruz et al., "Flowers from Kalanchoe pinnata are a rich source of T cell-suppressive flavonoids," Natural Product Communications, vol. 7, no. 2, pp. 175-178, 2012.

[11] E. Middleton Jr., C. Kandaswami, and T. C. Theoharides, “The effects of plant flavonoids on mammalian cells: implications for inflammation, heart disease, and cancer," Pharmacological Reviews, vol. 52, no. 4, pp. 673-751, 2000.

[12] A. B. Dongmo, T. Miyamoto, K. Yoshikawa, S. Arihara, and M.-A. Lacaille-Dubois, "Flavonoids from Acacia pennata and their cyclooxygenase (COX-1 and COX-2) inhibitory activities," Planta Medica, vol. 73, no. 11, pp. 1202-1207, 2007.

[13] Y. Takano-Ishikawa, M. Goto, and K. Yamaki, "Structureactivity relations of inhibitory effects of various flavonoids on lipopolysaccharide-induced prostaglandin $\mathrm{E}_{2}$ production in rat peritoneal macrophages: comparison between subclasses of flavonoids," Phytomedicine, vol. 13, no. 5, pp. 310-317, 2006.

[14] C.-C. Chen, M.-P. Chow, W.-C. Huang, Y.-C. Lin, and Y.-J. Chang, "Flavonoids inhibit tumor necrosis factor- $\alpha$-induced up-regulation of intercellular adhesion molecule-1 (ICAM-1) in respiratory epithelial cells through activator protein-1 and nuclear factor- $\kappa \mathrm{B}$ : structure-activity relationships," Molecular Pharmacology, vol. 66, no. 3, pp. 683-693, 2004.

[15] K. Morikawa, M. Nonaka, M. Narahara et al., "Inhibitory effect of quercetin on carrageenan-induced inflammation in rats," Life Sciences, vol. 74, no. 6, pp. 709-721, 2003.

[16] I. Peluso, A. Raguzzini, and M. Serafini, "Effect of flavonoids on circulating levels of TNF- $\alpha$ and IL- 6 in humans: a systematic review and meta-analysis," Molecular Nutrition \& Food Research, vol. 57, no. 5, pp. 784-801, 2013.

[17] P. J. Vacher, P. Duchéne-Marullaz, and P. Barbot, "A propos de quelques produits usuels-comparaison de deux méthodes d'étude des analgésiques," Medicina Experimentalis, vol. 11, pp. 51-58, 1964.
[18] D. B. M. Barbosa, M. V. M. Nascimento, R. C. Lino et al., "Mechanism involved in the anti-infl amatory effect of Spiranthera odoratissima (Manacá)," Brazilian Journal of Pharmacognosy, vol. 22, no. 1, pp. 137-143, 2011.

[19] G. F. Passos, E. S. Fernandes, F. M. da Cunha et al., "Antiinflammatory and anti-allergic properties of the essential oil and active compounds from Cordia verbenacea," Journal of Ethnopharmacology, vol. 110, no. 2, pp. 323-333, 2007.

[20] J.-M. Cherng, W. Chiang, and L.-C. Chiang, "Immunomodulatory activities of common vegetables and spices of Umbelliferae and its related coumarins and flavonoids," Food Chemistry, vol. 106, no. 3, pp. 944-950, 2008.

[21] K. Morikawa, M. Nonaka, M. Narahara et al., "Inhibitory effect of quercetin on carrageenan-induced inflammation in rats," Life Sciences, vol. 74, no. 6, pp. 709-721, 2003.

[22] S. C. Bischoff, "Quercetin: potentials in the prevention and therapy of disease," Current Opinion in Clinical Nutrition and Metabolic Care, vol. 11, no. 6, pp. 733-740, 2008.

[23] A. P. Rogerio, A. Kanashiro, C. Fontanari et al., "Antiinflammatory activity of quercetin and isoquercitrin in experimental murine allergic asthma," Inflammation Research, vol. 56, no. 10, pp. 402-408, 2007.

[24] M. P. Nair, S. Mahajan, J. L. Reynolds et al., "The flavonoid quercetin inhibits proinflammatory cytokine (tumor necrosis factor alpha) gene expression in normal peripheral blood mononuclear cells via modulation of the NF- $\kappa \beta$ system," Clinical and Vaccine Immunology, vol. 13, no. 3, pp. 319-328, 2006.

[25] J. H. Kwon, J. H. Kim, S. E. Choi, K. H. Park, and M. W. Lee, "Inhibitory effects of phenolic compounds from needles of Pinus densiflora on nitric oxide and $\mathrm{PGE}_{2}$ production," Archives of Pharmacal Research, vol. 33, no. 12, pp. 2011-2016, 2010.

[26] M. Ichikawa, M. Ogura, and T. Iijima, "Antiallergic flavone glycoside from Kalanchoe pinnatum," JP Patent 61,118, 396, 1986.

[27] L. R. Ballou, R. M. Botting, S. Goorha, J. Zhang, and J. R. Vane, "Nociception in cyclooxygenase isozyme-deficient mice," Proceedings of the National Academy of Sciences of the United States of America, vol. 97, no. 18, pp. 10272-10276, 2000.

[28] Z. Parveen, Y. Deng, M. K. Saeed, R. Dai, W. Ahamad, and Y. $\mathrm{H}$. Yu, "Antiinflammatory and analgesic activities of Thesium chinense Turcz extracts and its major flavonoids, kaempferol and kaempferol-3-O-glucoside," Yakugaku Zasshi, vol. 127, no. 8, pp. 1275-1279, 2007.

[29] Z. A. Zakaria, H. K. Gopalan, H. Zainal et al., "Antinociceptive, anti-inflammatory and antipyretic effects of Solanum nigrum chloroform extract in animal models," Yakugaku Zasshi, vol. 126, no. 11, pp. 1171-1178, 2006.

[30] P. V. Afonso, M. Janka-Junttila, Y. J. Lee et al., "LTB4 Is a SignalRelay Molecule during Neutrophil Chemotaxis," Developmental Cell, vol. 22, no. 5, pp. 1079-1091, 2012.

[31] T. S. Fröde, G. E. P. Souza, and J. B. Calixto, “The modulatory role played by TNF- $\alpha$ and IL- $1 \beta$ in the inflammatory responses induced by carrageenan in the mouse model of pleurisy," Cytokine, vol. 13, no. 3, pp. 162-168, 2001.

[32] M.-J. Sanz and P. Kubes, "Neutrophil-active chemokines in in vivo imaging of neutrophil trafficking," European Journal of Immunology, vol. 42, no. 2, pp. 278-283, 2012.

[33] H. N. Lee, H. J. Cho, D. Y. Lim, Y.-H. Kang, K. W. Lee, and J. H. Y. Park, "Mechanisms by which licochalcone e exhibits potent anti-inflammatory properties: studies with phorbol ester-treated mouse skin and lipopolysaccharide-stimulated murine macrophages," International Journal of Molecular Sciences, vol. 14, no. 6, pp. 10926-10943, 2013. 
[34] M. Afzal, G. Gupta, I. Kazmi et al., "Anti-inflammatory and analgesic potential of a novel steroidal derivative from Bryophyllum pinnatum," Fitoterapia, vol. 83, no. 5, pp. 853-858, 2012.

[35] C. M. Lima, A. K. Lima, M. G. D. Melo et al., "Bioassay-guided evaluation of Dioscorea villosa-an acute and subchronic toxicity, antinociceptive and anti-inflammatory approach," BMC Complementary and Alternative Medicine, vol. 13, article 195, 2013.

[36] Q.-S. Wang, L. Yang, W.-Y. Cui, L. Chen, and Y.-H. Jiang, "Anti-inflammatory and anti-nociceptive activities of methanol extract from aerial part of Phlomis younghusbandii Mukerjee," PLoS ONE, vol. 9, no. 3, Article ID e89149, 2014.

[37] N. Darshika Kodithuwakku, M. Pan, Y.-L. Zhu et al., "Antiinflammatory and antinociceptive effects of Chinese medicine SQ gout capsules and its modulation of pro-inflammatory cytokines focusing on gout arthritis," Journal of Ethnopharmacology, vol. 150, no. 3, pp. 1071-1079, 2013.

[38] A. D. Mancini and J. A. Di Battista, "The cardinal role of the phospholipase A2/cyclooxygenase-2/ prostaglandin e synthase/ prostaglandin E2 (PCPP) axis in inflammostasis," Inflammation Research, vol. 60, no. 12, pp. 1083-1092, 2011.

[39] M. Hämäläinen, R. Nieminen, M. Z. Asmawi, P. Vuorela, H. Vapaatalo, and E. Moilanen, "Effects of flavonoids on prostaglandin $\mathrm{E}_{2}$ production and on COX-2 and mPGES-1 expressions in activated macrophages," Planta Medica, vol. 77, no. 13, pp. 1504-1511, 2011.

[40] A. Koeberle, J. Bauer, M. Verhoff, M. Hoffmann, H. Northoff, and O. Werz, "Green tea epigallocatechin-3-gallate inhibits microsomal prostaglandin $\mathrm{E}_{2}$ synthase-1," Biochemical and Biophysical Research Communications, vol. 388, no. 2, pp. 350-354, 2009. 


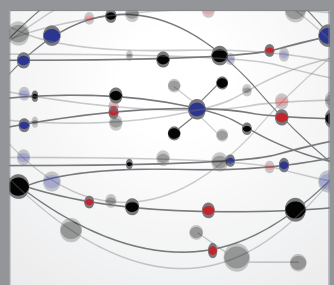

The Scientific World Journal
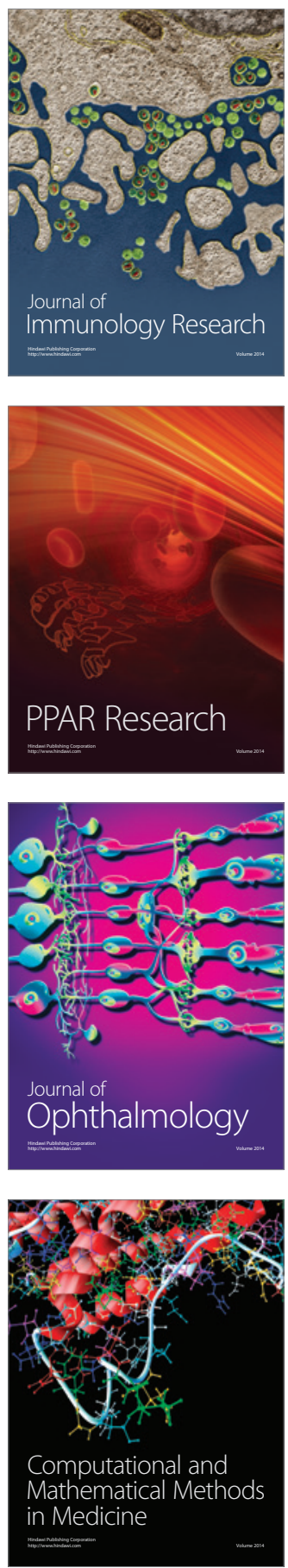

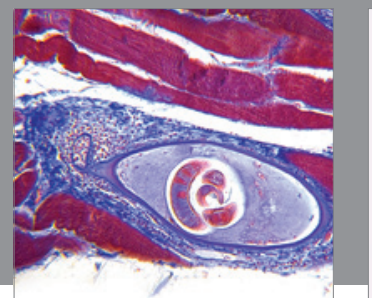

Gastroenterology

Research and Practice
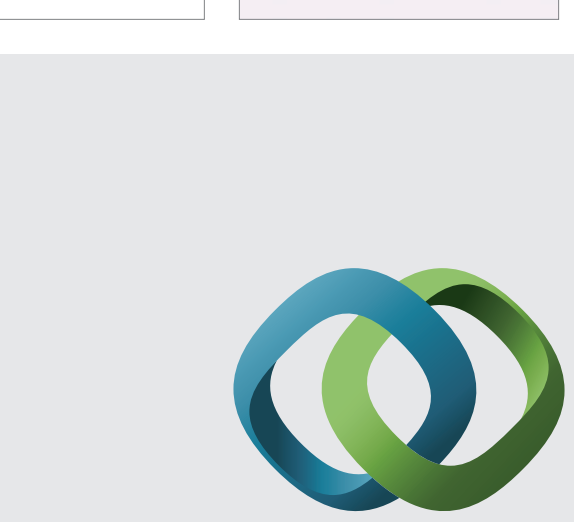

\section{Hindawi}

Submit your manuscripts at

http://www.hindawi.com
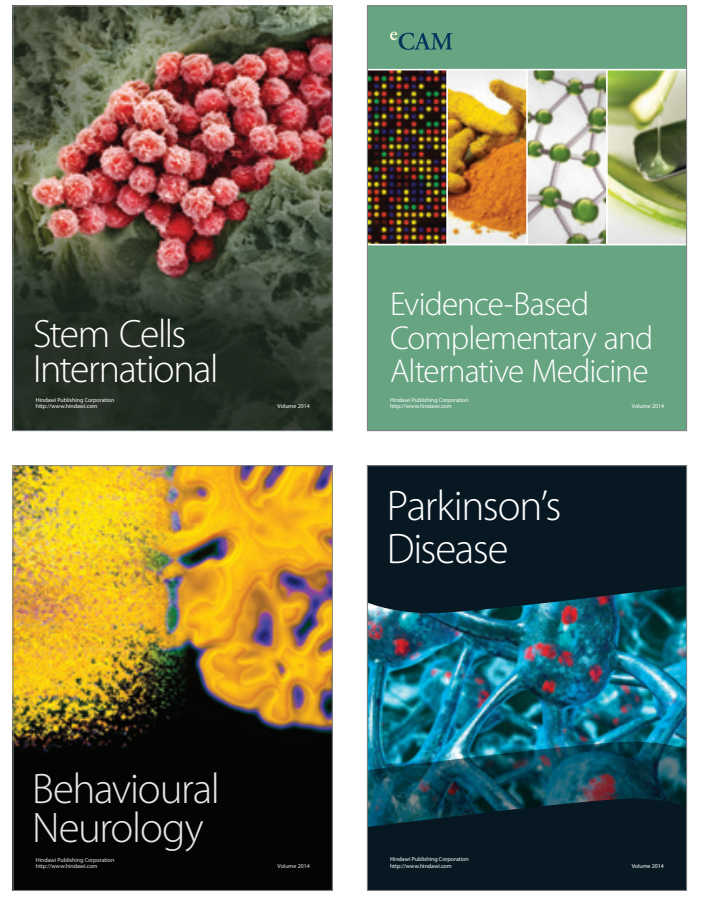
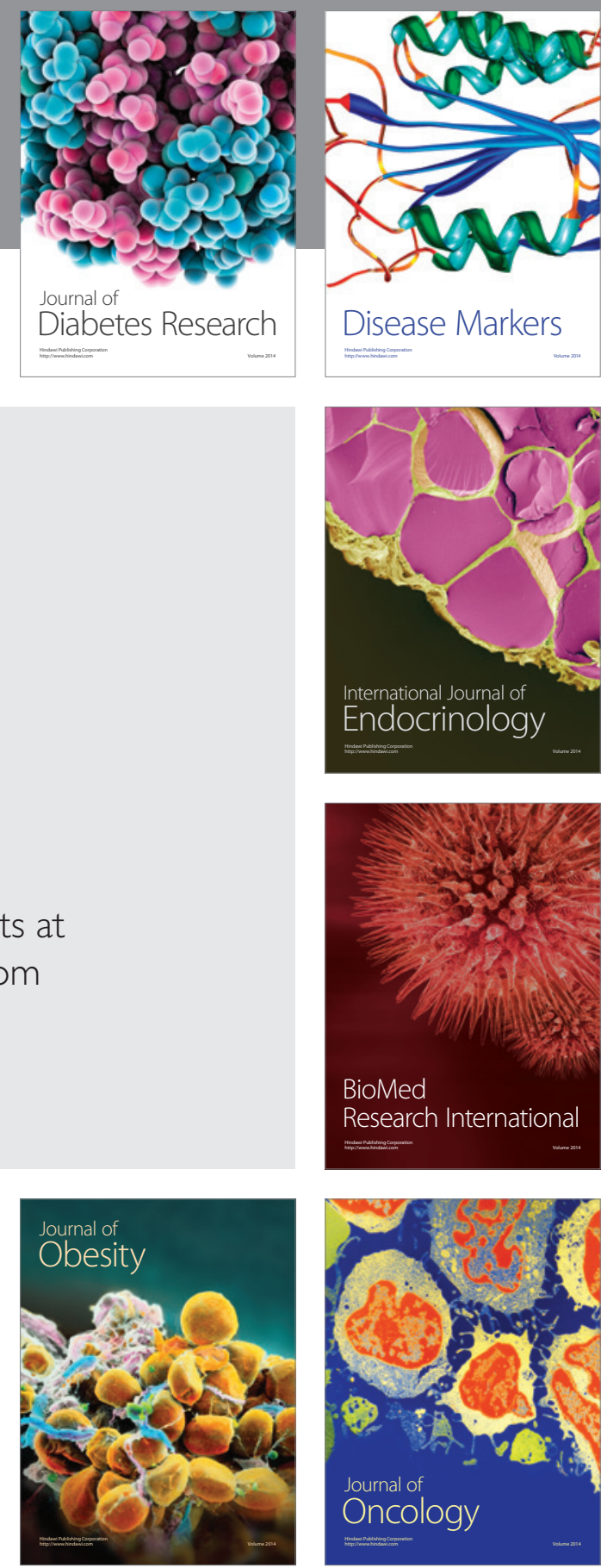

Disease Markers
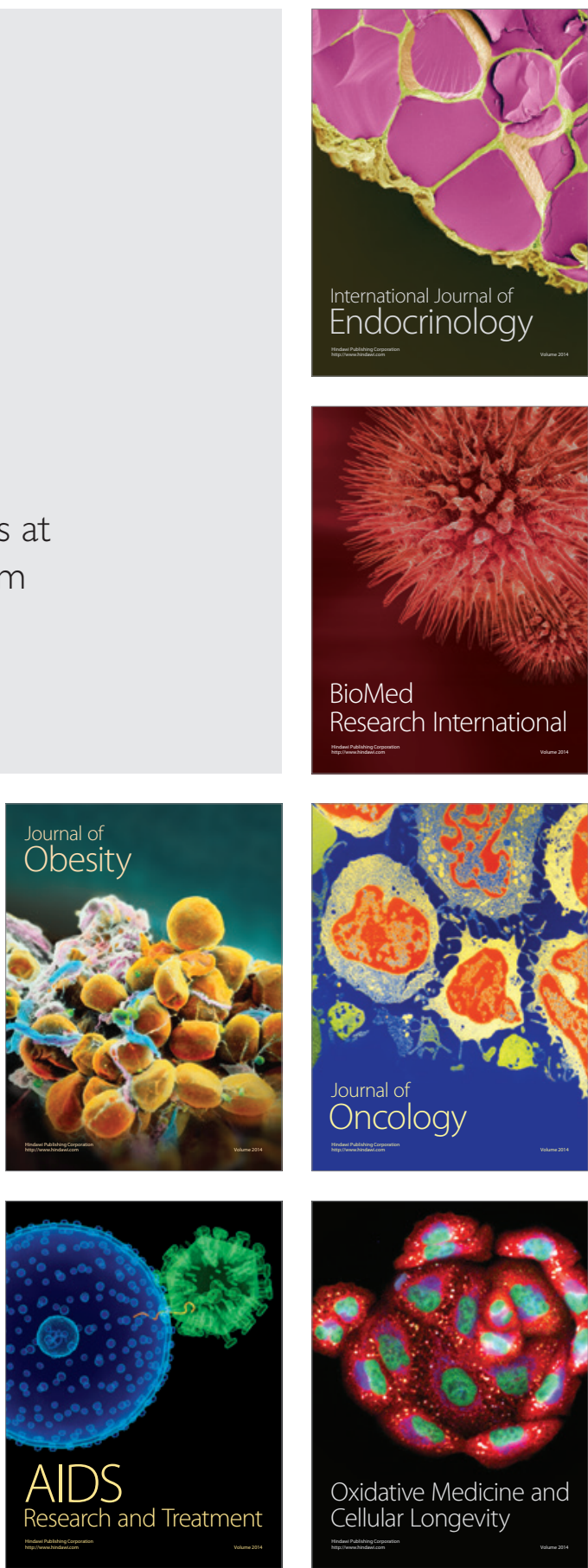